\title{
Awareness of Islamic banking products among Muslims: The case of Australia
}

Received (in revised form): 20th October, 2006

\section{Hussain Gulzar Rammal ${ }^{*}$}

is a lecturer in International Business at the University of Adelaide. He holds a bachelors degree from the University of Melbourne and a Master's degree from Flinders University. He has published in numerous international business journals in the areas of Islamic financing, international trade and international business negotiations.

\section{Ralf Zurbruegg}

is a professor of Finance at the University of Adelaide. He holds an undergraduate degree from the London School of Economics and a Masters degree and $\mathrm{PhD}$ from the University of Manchester. He has published over 70 articles, with the majority appearing in leading finance journals. His primary research interests lie in risk management issues, particularly as they relate to insurance, derivatives pricing and securitised real estate assets. He has consulted for numerous financial institutions over the years on risk management topics and is also the co-editor of the International Journal of Managerial Finance.

Abstract The purpose of this study is to examine the awareness of Muslim Australians of Islamic banking, particularly profit-and-loss sharing agreements. A sample of 300 Australian Muslims were surveyed utilising a short questionnaire containing specific questions relating to the willingness of respondents to purchase profit-and-loss sharing Islamic banking products. The results indicate that the majority of the respondents are interested in purchasing these products, but are not properly informed about how they function. It was common to find respondents who were keen to purchase Islamic banking products, but only if credit facilities were available. This is contrary to Islamic Shari'ah law, and suggests a lack of understanding of the principles of Islamic finance. Journal of Financial Services Marketing (2007) 12, 65-74. doi:10.1057/palgrave.fsm.4760060

Keywords Islamic financing, interest-free financing, profit-and-loss sharing, Australia

\section{INTRODUCTION}

The concept of interest-free financing was practiced by Arabs prior to the advent of Islam, and was later adopted by Muslims as an acceptable form of trade financing. While the system had been used on a small scale for centuries, its commercial application began in the 1970s. ${ }^{1}$ Since then Islamic financing has experienced worldwide acceptance, and by

${ }^{*}$ Correspondence: School of Commerce, The University of Adelaide, 233 North Terrace, Adelaide, South Australia 5005, Australia

Tel: +61883034513 ;

Fax: +61883037243 ;

e-mail: hussain.rammal@adelaide.edu.au early 2003 there were at least 176 Islamic banks around the world, with deposits in excess of $\$ 147 \mathrm{bn} .^{2}$

While Islamic financing has become popular in both Muslim and non-Muslim countries, the system has not achieved widespread success among Muslims in Australia. The main reason for this has been the lack of awareness about the principles of the system among the population. ${ }^{3}$

Australia's Muslim population is increasing at a rapid pace, and based on the requirement of Shari'ah, ${ }^{4}$ one would expect an increase in demand for Islamic financial products. This has certainly been true in the case of other non-Muslim majority nations like the UK, 
where the increase in demand for Islamic products has convinced bank regulators to provide permission for the operation of a purely Islamic Bank..$^{5}$ According to the census of the population conducted in 2001, there are more than 281,000 Muslims in Australia, which is equivalent to 1.5 per cent of the total Australian population. This marks an increase of 40 per cent in the Muslim population since the previous census was conducted in $1996 .^{6}$

Australia's experience with Islamic financing has been relatively recent. The first attempt to introduce Islamic financing products in Australia was made by the Muslim Community Co-operative Australia (MCCA). ${ }^{7}$ The organisation began in 1989 with AU $\$ 22,300$ worth of seeding capital and by 2003 had 5,600 members and deposits worth AU $\$ 24 \mathrm{~m} .{ }^{8}$ Majority of the MCCA members are from Melbourne and Sydney where the organisation has a physical presence. In 2001 another organisation, Iskan Finance, started providing Shari'ah-compliant home financing options. ${ }^{9}$

The purpose of this paper is to ascertain the awareness of, and demand for profitand-loss sharing Islamic financial products in Australia among the practicing Muslim population. This would represent the most likely purchasers of Islamic banking products in a country with a minority Muslim population. The paper is divided into five sections. The next section provides a brief overview of the Islamic financing system, followed by the third section which details the methodology used for this study. The fourth section reports on the findings and implications of this study, while the final section provides suggestions for further studies.

\section{THE ISLAMIC FINANCING SYSTEM}

Islamic financing is based upon the principle that the use of Riba (interest) is prohibited. ${ }^{10}$ This prohibition is based upon Shari'ah ruling. Since Muslims cannot receive or pay interest, they are unable to conduct business with conventional banks. ${ }^{11}$ To service this niche market, Islamic financial institutions have developed a range of halal ${ }^{12}$ interest-free financing instruments that conform to Shari'ah ruling, and therefore are acceptable to their clients. ${ }^{13}$

The idea of Islamic banking goes back to as early as the 7th century, but it was only commercially implemented in the last century. ${ }^{14}$ As the end of the colonial era approached, some of the newly formed and independent Muslim states reassessed their economic policies on the basis of Shari'ah principles. This marked the beginning of the present-day revival of Islamic finance. Smallscale limited scope interest-free institutions were unsuccessfully tried in the mid-1940s in Malaysia and 1950s in Pakistan. ${ }^{15}$ From 1946 onwards, research by Muslim scholars gradually produced principles for banking practices that were likely to be acceptable to the banking and Islamic communities. The first successful application of Islamic finance was undertaken in 1963 by Egypt's Mit Ghamr Savings Bank, which earned its income from profit-sharing investments rather than from interest. ${ }^{16}$ By the 1970s, the push for Islamic finance had gained momentum. In 1973 the conference of foreign ministers of Muslim countries decided to establish the Islamic Development Bank with the aim of fostering economic development and social progress of Muslim countries in accordance with the principles of Shari'ah. ${ }^{17}$ This marked the first major collective step taken by Muslim countries to promote Islamic finance.

The market leaders in this industry are Citigroup, HSBC, J.P. Morgan, and Standard Chartered who provide Islamic financing products through the use of Islamic windows (special facilities offered by conventional banks to provide services to Muslims who wish to engage in Islamic banking) ${ }^{18}$ While a number of Islamic financial products are now available, the most widely recognised profit-and-loss sharing instruments are 
Mudaraba (finance trusteeship) and Musharaka (equity partnership). Mudaraba is an agreement between two parties, where one provides finance to another for utilisation in an agreed manner. ${ }^{19}$ The financier of the venture is known as the Rabb-ul-mal, and the entrepreneur responsible for the management and execution of the project is referred to as the Mudarib. The parties achieve their returns by sharing in the profits of the venture, which are divided on a proportional basis. Under a Mudaraba agreement, returns cannot be provided as a lump sum, and cannot be guaranteed. To fulfill the requirements of this contract the parties must decide on a rate for sharing of the profits prior to the commencement of the business activity. After the business is completed the financier receives the principal and the pre-agreed share of the profit. The remainder of the profit is the entrepreneur's compensation for their ideas and services. ${ }^{15}$

The other profit-and-loss sharing instrument is Musharaka which refers to a joint partnership formed for conducting business in which all partners share the profit according to a specific ratio while the loss is shared according to the ratio of the contribution. ${ }^{16,20-22}$

The two profit-and-loss sharing instruments described above are the oldest form of interest-free financing found in ancient Arabia. Prior to the advent of Islam, wealthy Arab merchants financed the caravan trade and would share in the profits of a successful operation but could also lose all or part of their investment, if, for example, the merchandise was stolen, lost or sold for less than its cost. ${ }^{23}$ After the introduction of Islam, this system was permitted to continue and was legitimatised as a finance instrument. For this historical reason, scholars consider profit-and-loss sharing financial instruments to be the most authentic and most promising form of Islamic contracts. ${ }^{24}$ Yet, partly due to the high risk involved, while the Islamic Banks are expected to grow at an annual rate of around 15 per cent, profit-and-loss sharing constitutes only a small part (about 5 per cent) of their activities. ${ }^{25}$ To ensure that Islamic financing continues to follow the concept of linking returns to risks, many scholars have argued for a greater use of the profit-and-loss sharing products. ${ }^{21,24}$ Achieving this requires a deeper understanding and acceptance by the Muslim population of the principles of profit-and-loss sharing financing and the available alternatives.

\section{METHODOLOGY}

As the main focus of this paper is to examine the level of perceived awareness of halal banking among Muslim residents in Australia, a short questionnaire was formed containing specific questions relating to the willingness of respondents to purchase Islamic banking products. Also, questions were picked to distinguish between respondents who believe they were well informed about profitand-loss sharing agreements, and those who had previously owned (or currently own) a halal stylised banking product.

Originally, a pilot study was carried out utilising a host of questions on a small sample of individuals. These questions were conditional in nature and were used to determine the selection of sample population. The next step was to develop a short questionnaire that would be easy to understand and require minimal time to complete, six specific questions were chosen that (a) provided maximum coverage of the research questions we were interested in answering and (b) were not co-related questions. Specifically, this second point deals with the need for most questionnaires that ask a multitude of questions to undertake factor analysis to determine the relative groupings that constitute the framework of the questionnaire. Sometimes, however, factor analysis fails in as much as a subjective element is incorporated into this methodology in setting the appropriate number of latent factors inherent within 
the data. To avoid this issue, questions that were chosen were specifically selected to ensure the correlations between the variables were low, thereby ensuring each variable specifically targeted a question that could not easily be proxied by another.

The questionnaires were distributed simultaneously by three trained ${ }^{26}$ administrators to 300 respondents after Friday prayers at three different mosques during June 2004 in the city of Adelaide, Australia. The number of people available for the survey was far greater, but only those people meeting specific selection criteria were asked to complete the six questions. The selection criteria were devised to ensure only those people who (a) came from a Muslim background, and were practicing Muslims, (b) currently owned a bank account in Australia, (c) were interested in halal banking products, and (d) gainfully employed were selected (18 years and over). By default, 89 per cent of the respondents were male. This led to a sample data set of respondents with highly specific demographics. Our data set therefore analyses the awareness and willingness of this specific cohort of the population for undertaking halal accounts. This cohort also represents the demographic of most likely people any profit-and-loss sharing account would be catering for and so provides an interesting study on how well halal banking practices would sell under current informational conditions.

The results tabulated in the succeeding empirical section show cross-tabulations of how the respondents' answers were dependent on their perceived knowledge of halal style banking, plus prior experience with these products. Also, results from a logit model are presented, showing the significance of how respondents' familiarity with halal banking influenced their willingness to purchase halal banking products under various conditions. The logit model is a maximum likelihood regression where the dependent variable is a binary variable (yes $=1$ or no $=0$ answers). A standard linear regression would not be suitable, as the conditional mean equation would place unsuitable assumptions on the residuals of the model, as now the dependent variable can only vary between 0 and 1 . Instead, we model the probability of observing a value of 1 as a function of $F$, which is a continuous, increasing distribution that returns a value ranging from 0 to 1 . Specifically, for a latent variable $y_{i}$ that is linearly related to $x$, then the logit regression of:

$y_{i}=x_{i}^{\prime} \beta+u_{i}$ where $u_{i}$ is random noise and $\beta$ is a vector of coefficients for the independent variables, the probability of obtaining a $1 \mathrm{can}$ be written as:

$\operatorname{Pr}\left(y_{i}=1 \backslash x, \beta\right)=1-F\left(-x_{i}^{\prime} \beta\right)=1-\left(\mathrm{e}^{-x_{i}^{\prime} \beta} /\left(1+\mathrm{e}^{-x_{i}^{\prime} \beta}\right)\right)$

where $F$ is now a cumulative distribution function for the logistic distribution. The main difference with this type of regression and normal ordinary least squares regressions is that the coefficients of the explanatory variables do not show the marginal effect on the dependent variable. The sign and significance values attributed to the coefficients remain, however, the same. For example, the more positive a variable is, the greater the probability of a positive value being attributed to the dependent variable.

To provide a goodness-of-fit test for the above maximum likelihood regression, the Andrews $^{27} \chi^{2}$ test is performed for each regression. It tests to compare the fitted expected values to the actual values by specific groups. If the differences are significantly large, it indicates we should reject the model as producing a good fit to the actual data. Therefore, the null hypothesis is that the model is a good fit, with the alternative being that it is not. Standard Akaike and Log likelihood values are also reported. 


\section{EMPIRICAL RESULTS}

\section{Generalised results and contingency tables}

Table 1 shows the generalised answers to the six specific questions that were asked. It is interesting to note that from the outset, their perceived awareness of halal banking practices (profit-and-loss sharing agreements) among the selected pool of respondents is not particularly high, at 55.7 per cent. Even more so are the numbers of persons having previously held (or are holding) a halal stylised bank account, making up only 19.3 per cent of those surveyed. This is probably largely due to the lack of Islamic banking products in Australia in general.

Surprisingly, the lack of knowledge and experience with utilising halal bank products does not seem, at the face of it, to be a detriment to the willingness for people to purchase a halal bank account if the same facilities were available to them as that currently offered by the mainstream conventional banks. In fact, 92.5 per cent of the respondents were keen to be part of a profit-and-loss sharing arrangement. If we take a look at Tables 2 and 3, we can also break this figure up between those who answered yes and those answering no to having said they are aware of halal banking. The difference in the response they give is independent of how aware they believe they are of halal profit-and-loss sharing agreements, with 94 and 90.8 per cent of tıre respondents answering positively to purchasing a halal product regardless of whether they believe they are familiar with halal practices or not, respectively. A simple

Table 1 Proportional responses to survey queries

\begin{tabular}{llll}
\hline Query & Yes (\%) & No (\%) & N/A (\%) \\
\hline Awareness of halal banking products & 55.7 & 44.1 & 0.3 \\
Ever having held a halal stylised bank account & 19.3 & 80.1 & 0.7 \\
Willingness to switch to a halal product given same quality of & 92.5 & 7.4 & 1.5 \\
conventional banking service (ATM, online access, phone banking) & & 0 \\
Willingness to switch without credit facilities & 79.0 & 20.9 & 0.3 \\
Willing to switch to a profit-and-loss agreement where you might & 60.8 & 37.9 & 0.3 \\
incur losses & 60.1 & 39.7 & 0.3 \\
Willingness to switch dependent on brand recognition & & \\
\hline
\end{tabular}

Responses are quoted in percentage terms with N/A representing the proportion of missing responses for a particular question.

Table 2 Positive conditional responses to specific queries

\begin{tabular}{|c|c|c|c|c|c|c|}
\hline \multirow[t]{2}{*}{ Query } & \multicolumn{2}{|c|}{$\begin{array}{l}\text { Having held a halal } \\
\text { product }\end{array}$} & \multicolumn{2}{|c|}{$\begin{array}{l}\text { Aware of halal } \\
\text { banking products }\end{array}$} & \multicolumn{2}{|c|}{$\begin{array}{l}\text { Awareness of halal products } \\
\text { and willing to switch given } \\
\text { conventional bank service }\end{array}$} \\
\hline & Yes (\%) & No (\%) & Yes (\%) & No (\%) & Yes & No \\
\hline $\begin{array}{l}\text { Willingness to switch to a halal } \\
\text { product given same quality of } \\
\text { conventional banking service (ATM, } \\
\text { online access, phone banking) }\end{array}$ & 77.0 & 23.0 & 94.0 & 6.0 & - & - \\
\hline $\begin{array}{l}\text { Willingness to switch without credit } \\
\text { facilities }\end{array}$ & 76.9 & 23.1 & 78.1 & 21.9 & $82.7 \%$ & $17.3 \%$ \\
\hline $\begin{array}{l}\text { Willing to switch to a profit-and-loss } \\
\text { agreement where you might incur } \\
\text { losses }\end{array}$ & 77.0 & 23.0 & 65.7 & 34.3 & $70.3 \%$ & $29.6 \%$ \\
\hline $\begin{array}{l}\text { Willingness to switch dependent on } \\
\text { brand recognition }\end{array}$ & 67.4 & 32.6 & 67.3 & 32.7 & $66.9 \%$ & $33.1 \%$ \\
\hline
\end{tabular}

This table displays cross-tabulations for all affirmative (Yes) responses made to each specific query listed in the first column to subsequent queries asked to these same respondents in the first row. 
Table 3 Negative conditional responses to specific queries

\begin{tabular}{|c|c|c|c|c|c|c|}
\hline \multirow[t]{2}{*}{ Query } & \multicolumn{2}{|c|}{$\begin{array}{l}\text { Having held a halal } \\
\text { product }\end{array}$} & \multicolumn{2}{|c|}{$\begin{array}{l}\text { Aware of halal banking } \\
\text { products }\end{array}$} & \multicolumn{2}{|c|}{$\begin{array}{l}\text { Awareness of halal } \\
\text { products and willing to } \\
\text { switch given conventional } \\
\text { bank service }\end{array}$} \\
\hline & Yes (\%) & No (\%) & Yes (\%) & No (\%) & Yes (\%) & No (\%) \\
\hline $\begin{array}{l}\text { Willingness to switch to a halal } \\
\text { product given same quality of } \\
\text { conventional banking service } \\
\text { (ATM, online access, phone } \\
\text { banking) }\end{array}$ & 56.6 & 43.3 & 90.8 & 9.2 & - & - \\
\hline $\begin{array}{l}\text { Willingness to switch without credit } \\
\text { facilities }\end{array}$ & 79.4 & 20.6 & 80.8 & 19.2 & 82 & 18 \\
\hline $\begin{array}{l}\text { Willing to switch to a profit-and- } \\
\text { loss agreement where you might } \\
\text { incur losses }\end{array}$ & 56.6 & 43.3 & 55.1 & 44.7 & 27.7 & 72 \\
\hline $\begin{array}{l}\text { Willingness to switch dependent } \\
\text { on brand recognition }\end{array}$ & 58.0 & 41.9 & 37.7 & 54.6 & 55 & 45 \\
\hline
\end{tabular}

This table displays cross-tabulations for all negative (No) responses made to each specific query listed in the first column to subsequent queries asked to these same respondents in the first row.

Pearson chi-square test on the independence between the two questions results in a test statistic of 0.952 and probability value rejecting the null hypothesis of independence at 30.9 per cent, indicating these two factors are indeed statistically independent of each other.

One important point to highlight is that what the respondents consider awareness of profit-and-loss sharing agreements are not necessarily translated into the willingness to purchase a halal product if explicit consideration is made that losses are a real possibility. For example, even though 94 per cent of the respondents who answered yes to being aware of halal banking products said they were keen to take out a profit-and-loss sharing product, 21.9 per cent said they would not be interested if credit facilities were not available and 34.3 per cent would not if they might incur a loss. These results highlight an important facet of the data, which is that the respondents' perceived knowledge of halal banking practices are not necessarily in alignment with some of the more basic principles of Islamic banking, namely the inability to obtain credit (interestcharged) and possibility of experiencing a loss on a profit-and-loss sharing account. It is, however, also important to point out that those who answered no to being aware of halal profit-and-loss sharing practices, were also even less keen to buy a product if losses could occur (44.7 per cent). A Pearson chi-Square test reveals there is a dependent relationship between the two sets of queries at the 10 per cent significance level (with a chi-square statistic of 3.04).

Following on from this, respondents who indicated that they had prior experience in having held a halal banking product before were more likely to be willing to hold a profit-and-loss sharing account, regardless of whether losses were a possibility (77 per cent). Having held a halal banking product is, however, not a direct indicator of the willingness to purchase profit-and-loss sharing products. Respondents who answered no to either having owned a halal product before or even claim to be aware of halal practices are actually far more likely to be willing to purchase profit-and-loss sharing products even if credit facilities are not available (80.8 per cent).

\section{Regression results}

It is necessary to briefly comment on the cross-correlations presented in Table 4 before examining the regression results tabulated in 


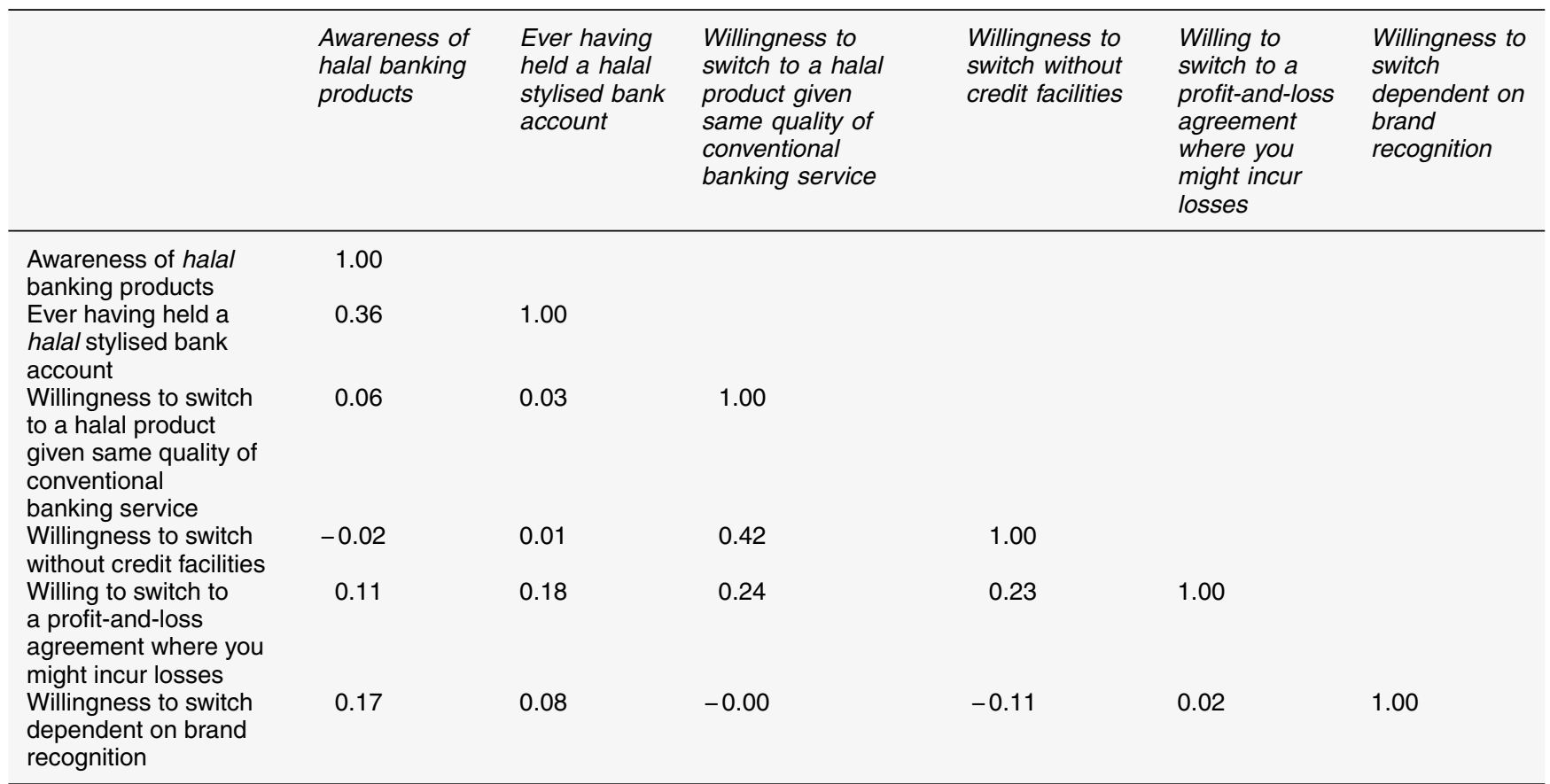

The values in the table represent correlation coefficients between each query listed in the first column with those queries in the first row.

Table 5. First, this table shows that none of the specified equations have a large correlation with any of the other questions, removing the problem of multicollinearity prevalent in many survey studies. Also, it is probably worthwhile spending some time looking at a few particular correlations. To begin, and although one would expect a high correlation to exist between those who stated they had owned a halal bank account and whether they claim to be aware of halal profit-and-loss sharing practices, the actual answer is, surprisingly, no. The correlation between the two is only 0.36 . This provides an indication that those who have or do hold halal banking products are perhaps more willing to acknowledge their own lack of awareness of the actual products, probably because they have had to actually deal with them. It also indicates that a large pool of those answering that they are aware of halal banking, have actually had no experience with any of the products.
Examining now the actual logit regression results, the statistics reveal an interesting picture on the willingness of the respondents to purchase profit-and-loss sharing. It should also be noted that one of the regressions only fail the Andrews goodness-of-fit test at the 10 per cent significance level.

Focusing in more detail on the first regression, it examines the possible determinants for a respondent to answer yes to being willing to buy a profit-and-loss sharing product despite possibly incurring losses, based on how they answered the other questions. As a compliment to the cross-correlations and the contingency tables already discussed, we are now able to examine the dynamic relationship these questions share in leading to this specific query response. Of all the questions, only the questions querying the respondents awareness of halal banking products and whether brand recognition is an important factor are not significant variables in determining whether 
Table 5 Logit regression results

\begin{tabular}{lcc}
\hline \multirow{2}{*}{ Explanatory variables } & \multicolumn{2}{c}{ Dependent variable } \\
\cline { 2 - 3 } & Query 6 & Query 7 \\
\hline Awareness of halal & 0.2085 & $0.6520^{\mathrm{a}}$ \\
banking products & $(0.2905)$ & $(0.2784)$ \\
Ever having held a & $1.0581^{\mathrm{a}}$ & 0.1400 \\
halal stylised bank & $(0.4200)$ & $(0.3669)$ \\
account & & \\
Willingness to switch & $1.4981^{\mathrm{a}}$ & 0.3225 \\
to a halal product & $(0.6285)$ & $(0.5511)$ \\
given same quality of & & \\
conventional banking & & \\
service & & \\
Willingness to switch & $0.9077^{\mathrm{a}}$ & $-0.7304^{\mathrm{b}}$ \\
without credit facilities & $(0.3585)$ & $(0.3828)$ \\
Willing to switch to a & - & 0.1061 \\
profit-and-loss & & $(0.2817)$ \\
agreement where you & & \\
might incur losses & & \\
Willingness to switch & 0.1095 & - \\
dependent on brand & $(0.2822)$ & \\
recognition & & \\
Constant & $-1.9898^{\mathrm{c}}$ & 0.2322 \\
Akaike info criterion & $(0.6359)$ & $(0.4859)$ \\
Log likelihood & 1.2569 & 1.3506 \\
Andrews Statistic: & -156.7798 & -168.9135 \\
& 15.4268 & $16.3331^{\mathrm{b}}$ \\
& $(0.1173)$ & $(0.0905)$ \\
\hline
\end{tabular}

aSignificance at the $5 \%$ critical level.

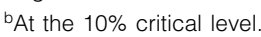

'Significance at the $1 \%$ critical level.

Query 6 asks the question 'Are you willing to switch to a profitand-loss agreement where you might incur losses'

Query 7 asks the question 'Would your decision to switch to a profit-and-loss sharing agreement be affected if the bank providing these services was well established (brand-recognition important)?

the respondent answers yes to being willing to purchase a profit-and-loss sharing account, despite incurring losses. This brings to the fore one very interesting matter; perceived awareness is not a strong determinant, at least for the case of purchasing profit-and-loss sharing products that might experience losses. Although this was briefly discussed before, when analysing the contingency tables, in this regression framework it also highlights the insignificance of the variable, relative to the other questions that were asked.

Following on from the above, the second regression places brand recognition as the dependent variable against all the other questions. In this case, only those people who perceive themselves as being aware of halal banking products is a significant determinant at the 5 per cent critical level. At the 10 per cent significance level, those respondents still willing to purchase profit-and-loss sharing accounts despite not having access to credit, are also statistically more likely to believe brand recognition is important. For the remainder of the questions, their impact on determining whether brand recognition is important is not significant. Whether respondents have previously held halal products, for example, or their interest in ensuring the same level of service as offered by other conventional banks seems to bare little impact on how important brand recognition is.

\section{IMPLICATIONS}

The findings indicate that the respondents would be receptive to the idea of purchasing Islamic financial products as long as the organisation that is providing the service is well known, and benefits such as ATM access, phone banking and so on, are provided. This provides a great opportunity for Australian financial institutions. If Australian organisations can build on their experience and reputation in the financial world, and can provide Islamic financial products in Australia, they can aim to gain a growing customer base of the Muslim population, some of who may have previously stayed away from dealing with the conventional financial institutions due to the use of interest. The MCCA has led the way in the Australian market. From humble beginnings in Melbourne where the brand was unknown, the organisation now has a large market share and continues to experience strong growth. ${ }^{7}$ Popular conventional banks such as the Australia and New Zealand Bank (ANZ) should, however, aim for even faster growth due to the high customer confidence in their brand name, and their ability to promote new products.

The findings also highlighted the lack of awareness in regards to the basic rules and principles of Islamic financing. The results indicate that a number of respondents would not take up halal financing options if credit 
facilities were taken away. In the Islamic financial system money is not lent out, instead it is an asset-backed system where financial institutions invest in projects. ${ }^{15}$ Therefore, financial institutions deal in equity, not debt. ${ }^{28}$ Providing credit facilities contravenes this principle. To counter this limitation, some financial institutions have started issuing 'debit' cards. These cards are similar to the credit cards except for the fact that they use the client's own funds instead of reliance on any credit.

Another issue is that of sharing profits and not losses. The results of the survey indicate that a number of respondents who had held a halal banking product were not aware of the loss sharing concept. This would indicate that some financial institutions have been guaranteeing profits. This contravenes the basic law of Islamic finance, that is, linking rewards to risk. Gains made on investment without risk is merely interest rather than profit.

In order to understand how the Islamic system differentiates between profit and interest, one has to look at the differences in economic ideology. In capitalist theory, capital and entrepreneurs are treated as two separate factors of production where the former gets interest and the latter is entitled to profit. It is assumed that interest is a fixed return for providing capital, and profit can only be earned after distributing the fixed return to land, labour and capital (in the form of rent, wage and interest). In contrast, the Islamic economic system does not consider capital and entrepreneurs as separate factors of production. ${ }^{25}$ It believes that every person who contributes capital in the form of money to a business venture assumes the risk of loss and therefore is entitled to a proportional share in the actual profit. ${ }^{29}$ The system is protective of the entrepreneur, who in a capitalist economy would have to make fixed interest repayments even when the venture is making a loss. ${ }^{22}$ Capital has an intrinsic element of entrepreneurship, so far as the risk of the business is concerned and therefore, instead of a fixed return as interest, it derives profit. The more the profit of the business, the higher the return on capital. With no fixed interest repayments, the profit would be higher. In this way the profits generated by the commercial activities in the society are equally distributed among those who have contributed capital to the enterprise.

Leading scholars in the area of Islamic Finance have declared that guarantees made by institutions that customers will receive a set rate of return without having to incur losses are illegal and unethical. Yet, not only are financial institutions continuing the practice but government agencies in Muslim countries are also offering investment opportunities with guaranteed profits. Considering that the Muslim governments are responsible for supervising the system in order to combat the illegal practices of financial institutions, by offering guaranteed returns the governments are seen to be condoning the behaviour of the financial institutions.

Although these actions may help Islamic Banks grow in the short run, the long-term costs (harm to reputation and authenticity) will outweigh the benefits. Such moves also provide ammunition to the critics of the system who are already questioning whether the system is nothing more than an interestbased system operating under the guise of profit. $^{30}$

\section{CONCLUSION}

As competition intensifies, financial institutions increasingly must be able to deliver personalised and customised financial solutions. Therefore, it is important for institutions to understand the dynamics of customer segmentation, build customer relationships and address requirements and preferences of specific segments of the market. From this, it is also important that financial institutions invest in new products to meet Islamic customer needs and demands, 
particularly as the Muslim population is growing in Australia at a rapid pace. Equally important is the need to develop an effective communication plan that goes beyond just marketing and advertisement to ensure the populace is aware of how Islamic banking products operate. As the results of this study show, institutions need to educate customers to adapt to the new ways of doing banking transactions, and understanding that Islamic finance involves the sharing of both profits and losses.

\section{References}

1 Naser, K. and Moutinho, L. (1997) 'Strategic marketing management: The case of Islamic banks', International Journal of Bank Marketing, Vol. 15, No. 6, pp. 187-203.

2 Ghannadian, F. F. and Goswami, G. (2004) 'Developing economy banking: The case of Islamic banks', International Journal of Social Economics, Vol. 31, No. 8, pp. $740-752$.

3 Jalaluddin, A. (2002) 'Probability of lending funds on profit/loss sharing method of finance by Australian financial institutions', Indonesian Management \& Accounting Research, Vol. 1, No. 1, pp. 71-84.

4 Shari'ah refers to Islamic law, which is based on the teachings of the Quran.

5 BBC News Business. (2004) 'First Islamic bank to open in UK', 9 August.

6 Australian Bureau of Statistics. (2003) 'Year Book Australia 2003', Australian Bureau of Statistics, Canberra.

7 Saeed, A. (2001) 'Muslim Community Cooperative of Australia as an Islamic financial service provider', in Saeed, A. and Akbarzadeh, S. (eds) 'Muslim Communities in Australia', UNSW Press, Sydney, pp. 188-205.

8 Butterly, N. (2003) 'Where loans are 'free' of interest', Sunday Herald Sun (Melbourne), 18 May, p. 85.

9 Iskan Finance. (2004) 'Who is Iskan?' [Online accessed 13 May 2005]. Available: http://www.iskan.com.au/intro_who.htm.

10 Gerrard, P. and Cunningham, J. B. (1997) 'Islamic banking: A study in Singapore', International Journal of Bank Marketing, Vol. 15, No. 6, pp. 204-216.

11 Jaffe, C. A. (2002) 'Financial forms tailor products to lure muslims', Boston Globe, 20 January.
12 Halal: Products that fulfill the criteria laid out by Islam of being acceptable for use.

13 Malaysian Business. (2001) 'A welcome alternative', Malaysian Business, December 16.

14 De Jonge, A. (1996) 'Islamic law and the finance of international trade', Monash University Working Paper, Melbourne.

15 Gafoor, A. L. M. (1996) 'Interest-Free Commercial Banking', A.S. Noordeen, Malaysia.

16 Lewis, M. K. and Algaoud, L. M. (2001) 'Islamic Banking', Edward Elgar, Cheltenham, UK.

17 Saeed, A. (1996) 'Islamic Banking And Interest: A Study Of The Prohibition Of Riba And Its Contemporary Interpretation', E.J. Brill, Leiden, The Netherlands.

18 Day, P. (2003) 'Sticking to (Islamic) law reaps rich rewards', The Australian Financial Review (Sydney), 13 March, p. 17.

19 Usmani, M. T. (1998) 'An Introduction To Islamic Finance', Idaratul Ma'arif, Karachi, Pakistan.

20 Haron, S., Ahmad, N. and Planisek, S. L. (1994) 'Bank patronage factors of Muslim and non-Muslim customers', International Journal of Bank Marketing, Vol. 12, No. 1, pp. $32-40$.

21 Rammal, H. G. (2004) 'Financing through Musharaka: Principles and application', Business Quest [Online accessed 10 July 2005]. Available: http://www.westga. edu/ bquest/2004/musharaka.htm.

22 Usmani, M. I. (2002) 'Meezanbank's Guide To Islamic Banking', Darul-Ishaat, Karachi, Pakistan.

23 Gafoor, A. L. M. (2001) 'Mudaraba-based investment and finance' [Online accessed 20 July 2005]. Available: http:// www.islamicbanking.nl/article2.html.

24 Rammal, H. G. (2003) 'Mudaraba in Islamic finance: Principles and application', Business Journal For Entrepreneurs, Vol. 4, pp. 105-112.

25 Warde, I. (2000) 'Islamic Finance In The Global Economy', Edinburgh University Press, Edinburgh.

26 The three administrators were practicing members of the Adelaide Muslim community. The administrators were experienced in administering surveys, and were provided information on Islamic finance.

27 Andrews, D. W. K. (1988) 'Chi-square diagnostic tests for econometric models: Introduction and applications', Journal of Econometrics, Vol. 37, pp. 135-156.

28 Siddiqui, M. N. (1987) 'Partnership And Profit-Sharing In Islamic Law', The Islamic Foundation, Leicester, UK

29 Siddiqui, M. N. (1994) 'Issues In Islamic Banking: Selected Papers', The Islamic Foundation, Leicester, UK.

30 The Economist. (1994) 'Islam And The West: A Survey The Cash-Flow Of God', August 6, pp. 9-10. 